\title{
Kandungan Gizi, Beta Karoten dan Antioksidan pada Tepung Pisang Tongka Langit (Musa troglodytarum L.)
}

\author{
Nutrient Content, Beta Carotene and Antioxidant on Tongka langit (Musa troglodytarum L.) Banana Flour
}

\author{
Ika Yohanna Pratiwi*, Oki Krisbianto
}

Program Studi Teknologi Pangan, Universitas Ciputra, Citraland CBD Boulevard, Sambikerep, Surabaya 60219, Indonesia

*Email: ika.yohanna@ciputra.ac.id

Tanggal submisi: 30 November 2017; Tanggal penerimaan: 27 Februari 2019

\begin{abstract}
ABSTRAK
Pisang Tongka Langit (Musa troglodytarum L.) merupakan tanaman khas Maluku yang diyakini berdampak positif bagi kesehatan, seperti meredakan panas dalam, membersihkan ginjal, dan menjaga kesehatan pencernaan. Namun, buah ini belum banyak dimanfaatkan maupun diteliti. Penelitian ini bertujuan mengetahui kandungan gizi tepung pisang tongka langit (TPTL), kandungan karoten dan beta karoten, serta aktivitas antioksidannya. Pisang Tongka Langit diolah menjadi tepung pisang kemudian dianalisa kadar air, abu, protein, serat, karbohidrat, vitamin $\mathrm{C}$, mineral, karotenoid, dan antioksidannya. Hasil penelitian menunjukkan adanya kandungan gizi yang tinggi pada tepung pisang Tongka Langit, yaitu energi sebesar 331,03 kalori, protein 4,66\%, karbohidrat 83,72\%, dan serat pangan total $16,59 \%$. Tepung pisang ini mengandung $7,92 \mathrm{mg} / 100 \mathrm{mg}$ total karotenoid dengan kandungan beta karoten sebesar $18,56 \%$. Selain itu, tepung pisang ini juga mengandung komponen antioksidan berupa flavonoid sebesar $0,35 \mathrm{mg} / \mathrm{kg}$ dan aktivitas antioksidan yang cukup tinggi.
\end{abstract}

Kata kunci: Antioksidan; tepung pisang; beta karoten

\begin{abstract}
Banana fruit cultivar Tongka Langit is a typical plant from Moluccas which has not widely used and observed just yet. It has been believed and used by locals to relieve body heat, clean the kidneys, and keep the health of the digestion tract, but without scientific proof. This study aims the nutrition content of Tongka Langit flour, along with its carotenoids, beta carotene, and antioxidant content. The banana fruit was dried at 60 oC for 2 hours. Banana flour had been analyzed for moisture content, levels of ashes, levels of protein, the fibers, carbohydrates, vitamin $\mathrm{C}$, mineral, carotenoids and antioxidant. It had been found that Tongka Langit flour contained 331,03 calories, 4,66\% protein, 83,72\% carbohydrate and 16,59\% dietary fibers. Tongka Langit flour contained 7,92 mg/ $100 \mathrm{mg}$ carotenoid total which $18,56 \%$ was beta carotene. As much as $0.35 \mathrm{mg} / \mathrm{kg}$ flavonoid was also found, along with its high level of antioxidant activity.
\end{abstract}

Keywords: Antioxidant; beta carotene; banana flour 


\section{PENDAHULUAN}

Pisang Tongka Langit merupakan spesies pisang khas Maluku yang memiliki kulit buah berwarna kuning kemerahan. Pisang ini diyakini penduduk lokal memiliki banyak manfaat bagi kesehatan, seperti meredakan panas dalam, membersihkan ginjal, dan menjaga kesehatan pencernaan. Namun, klaim tersebut sejauh ini masih belum ada yang membuktikannya secara ilmiah. Samson dkk. (2013) menemukan secara kualitatif bahwa pisang tongka langit mengandung karotenoid, terutama beta karoten.

Buah pisang Tongka Langit umumnya tidak dikonsumsi secara langsung, melainkan diolah terlebih dahulu seperti direbus dan dibakar, dan dikonsumsi sebagai makanan pokok. Kandungan pati buah pisang yang cukup tinggi sangat sesuai untuk diolah menjadi tepung. Penepungan sendiri merupakan salah satu bentuk pengolahan yang cukup lazim dalam Teknologi Pangan. Penepungan dapat memperpanjang umur simpan produk pertanian dan mempermudah pengembangannya menjadi berbagai produk seperti roti, kue, biskuit, bubur, dan lain-lain. Selain itu, budaya makan tepung akan menghasilkan makanan yang bervariasi dan bisa disesuaikan dengan kebudayaan dan kemampuan di daerah masing-masing sehingga menjadi pangan nasional, yang secara otomatis akan menumbuhkan industri pangan dan menyempurnakan apa yang selama ini sudah ada (Suryana dkk., 2004). Salah satu bentuk kreasi pengolahan tepung pisang adalah sebagai substitusi pembuatan makanan ringan seperti bolu kering (Pratomo, 2013); kerupuk (Wahyuningtyas, dkk., 2014); snack bar (Ekafitri, dkk., 2013); bahkan bubur bayi (Nurhayati, dkk., 2015). Meskipun demikian, perlu digarisbawahi bahwa bahwa perbedaan jenis bahan baku pisang sangat mempengaruhi kandungan nutrisi, sifat fisik, dan organoleptik tepung pisang yang dihasilkan (Nurhayati, dkk., 2015; Palupi, 2012).

Penelitian ini bertujuan mengetahui kandungan gizi tepung pisang tongka langit (TPTL), kandungan karoten dan beta karoten, serta aktivitas antioksidannya. Pengujian yang dilakukan meliputi analisis proksimat, serat pangan, karoten, beta karoten, vitamin $\mathrm{C}$ dan kapasitas antioksidan.

\section{METODE PENELITIAN}

\section{Bahan}

Buah pisang Tongka Langit diperoleh dari Desa Hutumuri, Kecamatan Leitimur Selatan, Kota Ambon, Maluku. Buah pisang dipanen pada minggu ketiga (masak tetapi belum matang), dibersihkan dan dikemas dalam kondisi tertutup rapat, selanjutnya dikirim ke
Surabaya menggunakan transportasi udara selama satu hari perjalanan. Sesampai di Surabaya, pisang disimpan pada suhu ruang paling lama satu hari sebelum diolah menjadi tepung pisang.

\section{Pembuatan Tepung Pisang Tongka Langit (TPTL)}

Buah pisang dikupas kemudian diiris tipis setebal $2 \mathrm{~mm}$, ditata setebal satu lapis pada loyang, kemudian dikeringkan dalam oven (SINMAG, Taiwan) pada suhu $60{ }^{\circ} \mathrm{C}$ selama 2 jam. Irisan pisang yang telah kering dihancurkan dengan grinder (Philips, HR-2116) kemudian diayak dengan ukuran 60 mesh.

\section{Analisa}

Tepung pisang Tongka Langit (TPTL) dikemas dalam plastik kedap udara dan disimpan dalam kotak berwarna gelap pada suhu $25^{\circ} \mathrm{C}$ hingga digunakan. TPTL dianalisa proksimat, kandungan beta karoten, total flavonoid, dan kapasitas antioksidan DPPH. Analisa proksimat dilakukan di Laboratorium Pangan dan Gizi, Fakultas Teknologi Pertanian, Universitas Gadjah Mada. Analisa beta karoten dilakukan di BioChem Surabaya. Analisa total flavonoid dan antioksidan DPPH dilakukan di LPPT UGM.

\section{Analisa Proksimat dan Serat Pangan}

Analisa proksimat yang dilakukan meliputi uji kadar air, kadar abu, protein, lemak, serat kasar, dan karbohidrat. Metode gravimetri untuk analisa kadar air, metode pengabuan langsung untuk kadar abu, metode mikro-Kjeldhal untuk kadar protein, metode gravimetri untuk serat kasar, dan perhitungan karbohidrat by different menggunakan prosedur AOAC (2016). Metode ekstraksi Petroleum Ether untuk kadar lemak berdasarkan prosedur Sudarmadji, dkk. (2010). Analisa serat pangan yang digunakan dalam penelitian ini ialah enzimatik-gravimetri berdasarkan AOAC Official Method 985.29; 993.19; dan 991.42.

\section{Analisa Beta karoten}

Penetapan kadar karoten pada sampel tepung pisang yang telah diekstraksi dengan petroleum eter dan diukur serapannya menggunakan spektrofotometer ultraviolet-visible (UV-VIS) pada panjang gelombang 420 nm (Samson dkk.,2013).

\section{Analisa Antioksidan}

\section{Analisa total flavonoid}

Pembuatan kurva standar dilakukan dengan cara baku standar quercetin ditimbang sebanyak 10 $\mathrm{mg}$ lalu ditambah $0,3 \mathrm{ml}$ natrium nitrit $5 \%$. Setelah 5 
menit ditambahkan $0,6 \mathrm{~mL}$ aluminium chloride $10 \%$ dan ditunggu 5 menit lalu ditambahkan $2 \mathrm{~mL}$ natrium hidroksida $1 \mathrm{M}$. Aquades ditambahkan ke dalam labu takar hingga $10 \mathrm{~mL}$ lalu dipindahkan ke dalam kuvet dan ditera serapannya pada panjang gelombang 510 $\mathrm{nm}$.

Penetapan contoh uji total flavonoid dilakukan dengan cara sampel ditimbang sebanyak $50 \mathrm{mg}$ dimasukkan ke dalam labu godog dan ditambahkan $10 \mathrm{~mL}$ asam chloride $2 \mathrm{~N}$ lalu di-reflux selama 30 menit dan didinginkan. Hasil reflux diekstraksi dengan $10 \mathrm{~mL}$ dietil eter kemudian diambil fase dietil eter dan diulang sebanyak 2 kali. Fase dietil eter diuapkan dengan hembusan gas nitrogen hingga kering dan ditambahkan $0,3 \mathrm{~mL}$ natrium nitrit $5 \%$. Setelah 5 menit ditambahkan $0,6 \mathrm{~mL}$ aluminium chloride $10 \%$ dan ditunggu 5 menit lalu ditambahkan $2 \mathrm{~mL}$ natrium hidroksida $1 \mathrm{M}$. Aquades ditambahkan ke dalam labu takar hingga $10 \mathrm{~mL}$ lalu dipindahkan ke dalam kuvet dan ditera serapannya pada panjang gelombang 510 nm (Julkunen-Tiitto, R. 1985).

\section{Aktivitas Antioksidan}

Penentuan aktivitas penangkal (scavenger) radikal bebas menurut Burda dan Oleszek (2001). Sebanyak 0,5 mL sampel ditambahkan $2 \mathrm{~mL}$ larutan 1,1-difenil-2pikrilhidrazil (DPPH) $93 \mu \mathrm{M}$ dalam etanol dan divorteks selama 2 menit. Tingkat berkurangnya warna dari larutan menunjukkan efesiensi penangkap radikal. Kemudian diinkubasi selama 30 menit, absorbansi diukur dengan spektrofotometer pada $\lambda 517 \mathrm{~nm}$. Aktivitas penangkap radikal bebas dihitung sebagai persentase berkurangnya warna DPPH dengan menggunakan Persamaan 1.

Aktivitas penangkal radikal bebas $(\%)=\left[1-\frac{\text { absorbansi sampel }}{\text { absorbansi kontrol }}\right] \times 100 \%$

\section{HASIL DAN PEMBAHASAN}

\section{Spesifikasi Pisang dan Tepung Pisang}

Pisang Tongka Langit memiliki kulit buah yang tebal, dengan berat kulit pisang sekitar dua kali lipat berat daging buahnya. Dari daging buah pisang segar, rendemen TPTL yang dihasilkan adalah sekitar $25-28 \%$. Hasil rendemen ini lebih tinggi dibandingkan dengan rendemen tepung pisang kepok dalam penelitian Wahyuningtyas, dkk. (2014), yaitu sekitar 20-24\%. Histifarina, dkk. (2012) menemukan rendemen tepung pisang siam, lumut, dan kepok sebesar 11-15\%; sementara rendemen tepung pisang nangka sebesar 27,48\%. Mereka menduga bahwa rendemen tepung pisang sangat dipengaruhi kadar air dan kadar pati buah pisang segar yang digunakan, yang juga dipengaruhi tingkat kematangan buah pisang. Semakin tinggi tingkat kematangan buah pisang, kadar patinya menurun secara signifikan karena dibongkar menjadi berbagai jenis gula seperti glukosa, fruktosa, sukrosa, dan maltosa oleh berbagai enzim hidrolase karbohidrat (Gao dkk., 2016).

Buah pisang Tongka Langit yang digunakan adalah yang masih masak (sudah layak dimakan tetapi masih belum matang) dikarenakan pisang yang sudah matang memiliki kadar gula yang cukup tinggi sehingga menjadi lengket, menggumpal, dan berwarna lebih gelap saat dipanaskan. Proses tersebut disebabkan terjadinya proses karamelisasi dan maillard. Kandungan gula yang tinggi juga menyebabkan tepung pisang yang sudah matang bersifat lebih higroskopis dibanding tepung dari pisang masak. Selain itu, berbagai penelitian dan industri pengolahan tepung pisang memilih bahan baku pisang masak yang masih berwarna hijau karena memiliki kandungan pati yang paling tinggi (da Mota, dkk., 2000) dan menghasilkan tepung pisang dengan kualitas terbaik dibandingkan pisang mentah, matang, dan sangat matang (Harefa dan Pato, 2017).

Standar Nasional Indonesia (SNI 01-3841-1995) untuk tepung pisang masak dan matang dibedakan, yaitu jenis $A$ untuk tepung pisang matang dan jenis $B$ untuk tepung pisang masak. Tepung pisang mentah lebih sesuai digunakan untuk produk kue dan tepung pisang matang lebih sesuai untuk produk roti (Pragati, dkk., 2014). Produk pangan yang disubstitusi tepung pisang juga memiliki kecenderungan berwarna lebih gelap dikarenakan proses karamelisasi dan maillard akibat kadar gula pada tepung pisang (Wahyuningtyas, dkk., 2014).

Tepung pisang Tongka Langit yang dihasilkan memiliki warna kuning cerah, beraroma sedikit masam khas pisang Tongka Langit, dan berbentuk bubuk yang halus. Tidak ada perubahan warna dan aroma yang signifikan pada tepung yang disimpan selama 3 bulan dalam wadah tertutup dan suhu kamar. Spesifikasi sensoris yang dimiliki TPTL disebabkan kandungan komponen non-pati.

\section{Kandungan Gizi}

Penelitian yang dilakukan oleh Palupi (2012) menyatakan bahwa perbedaan jenis bahan baku pisang berpengaruh signifikan terhadap kandungan gizi tepung pisang yang dihasilkan, seperti kadar air, protein, lemak, abu, serat, dan pati. Tiap 100 gram TPTL memiliki energi yang tinggi yaitu 331,03 kalori; lebih tinggi dibandingkan pisang siam yang hanya memiliki mengandung 268 kalori (Depkes RI, 1990).

Hasil uji proksimat TPTL disajikan pada Tabel 1. Kadar air TPTL sudah memenuhi SNI 01-3841-1995 
jenis $B$ (untuk pisang masak), yaitu kurang dari $12 \%$. Dibandingkan tepung pisang kepok, lumut, siam, dan nangka yang diteliti oleh Histifarina, dkk. (2012), TPTL mengandung kadar lemak cukup rendah dan kadar abu yang paling tinggi. Kadar lemak TPTL juga berada dalam rentang kadar lemak tepung pisang masak dari enam varietas pisang di Brazil, yang berkisar antara 0,33-0,82\%; sementara kadar abunya lebih tinggi dibandingkan tepung pisang yang sama, yang berkisar antara 2,6-3,5\% (da Mota, dkk., 2000).

Tabel 1. Kandungan gizi pada Tepung Pisang Tongka Langit (per $100 \mathrm{~g}$ )

\begin{tabular}{ll}
\hline Parameter & Hasil \\
\hline Air $(\%)$ & $6,91 \pm 0,21$ \\
Abu (\%) & $4,41 \pm 0,24$ \\
$\quad$ Kalium $(\mathrm{mg} / 100 \mathrm{~g})$ & $301,38 \pm 1,58$ \\
$\quad$ Kalsium $(\mathrm{mg} / 100 \mathrm{~g})$ & $12,34 \pm 0,18$ \\
$\quad$ Natrium $(\mathrm{mg} / 100 \mathrm{~g})$ & $13,41 \pm 0,11$ \\
$\quad$ Magnesium $(\mathrm{mg} / 100 \mathrm{~g})$ & $8,15 \pm 0,09$ \\
Lemak (\%) & $0,47 \pm 0,02$ \\
Protein total $(\%)$ & $4,66 \pm 0,08$ \\
Serat kasar $(\%)$ & $1,43 \pm 0,15$ \\
Karbohidrat $(\%)$ & $83,72 \pm 0,78$ \\
Energi (kal) & $331,03 \pm 1,72$ \\
\hline
\end{tabular}

Kandungan mineral yang cukup signifikan pada TPTL adalah kalium sebesar $301,38 \mathrm{mg} / 100 \mathrm{~g}$, jauh lebih tinggi dibandingkan natrium yaitu $13,41 \mathrm{mg} / 100 \mathrm{~g}$. Penelitian menunjukkan bahwa mineral kalium, magnesium, dan kalsium, bersama dengan serat pangan, memberikan sifat protektif terhadap hipertensi dan stroke (Krummel, 2008). Berbagai penelitian membuktikan bahwa buah pisang memiliki sifat fungsional dalam menurunkan resiko hipertensi pada wanita hamil (Pujiani dkk., 2017) dan orang tua (Pramono, dkk, 2017), serta gangguan susah tidur yang disebabkan oleh hipertensi (Ristania dkk., 2017). Meskipun cukup banyak penelitian yang mendukung manfaat kesehatan pisang maupun tepung pisang terhadap kesehatan, khususnya hipertensi, masih diperlukan penelitian lebih lanjut secara in vivo untuk dapat mengklaim TPTL sebagai makanan fungsional.

\section{Kandungan Serat Pangan}

Dalam penelitian gizi, kadar serat pangan memiliki arti yang jauh lebih signifikan terhadap kesehatan dibandingkan kadar serat kasar, misalnya untuk pencegahan penyakit degeneratif. Octavia, dkk. (2017) menyebutkan bahwa penurunan kadar trigliserida dan kolesterol pada tikus dengan sindrom metabolik yang
Tabel 2. Kandungan serat pangan Tepung Pisang Tongka Langit

\begin{tabular}{lr}
\hline Parameter & \multicolumn{1}{c}{ Hasil $(\%)$} \\
\hline Serat pangan larut air & $11,92 \pm 0,17$ \\
Serat pangan tidak larut air & $4,67 \pm 0,03$ \\
Serat pangan total & $16,59 \pm 0,20$ \\
\hline
\end{tabular}

diberi yogurt sinbiotik tepung pisang tanduk disebabkan oleh adanya bakteri probiotik serta kandungan serat pangan pada tepung pisang. Serat pangan berfungsi sebagai prebiotik yang mendukung pertumbuhan bakteri pencernaan yang baik bagi kesehatan manusia, juga menghambat absorpsi lipida di usus. Menurut American Heart Association (2016), asupan harian serat pangan yang dianjurkan untuk orang dewasa dengan kebutuhan kalori sebesar 2000 kalori adalah minimal sebanyak $25 \mathrm{~g}$.

Kandungan serat pangan larut, tidak larut, dan total dari TPTL ditunjukkan pada Tabel 2. Tingginya kandungan serat pangan TPTL dipengaruhi tingkat kematangan pisang Tongka Langit yang digunakan. Menurut penelitian Pragati dkk. (2014), tepung dari pisang belum matang memiliki kadar serat pangan yang lebih tinggi dibandingkan tepung pisang matang. Selain itu, proses pemanasan dalam pembuatan tepung juga berpengaruh signifikan dalam meningkatkan kandungan serat pangan tepung pisang, khususnya pati resistan (Abdillah, 2010). Pati resistan sendiri merupakan salah satu komponen serat pangan yang tidak larut air (Lattimer dan Haub, 2010).

Dibandingkan kandungan serat pangan tidak larut air tepung pisang dari enam varietas pisang di Brazil, yang berkisar antara 4,10-12,56\%, kandungan serat pangan tidak larut air TPTL cukup rendah. Namun, serat pangan larut airnya sangat tinggi dibandingkan tepung pisang yang sama, yang berkisar antara 2,10-3,05\% (da Mota, dkk., 2000).

\section{Kandungan Karoten, Beta Karoten, Vitamin C, dan Antioksidan}

Penelitian sebelumnya menyatakan adanya kandungan karotenoid dalam pisang tongka langit sebanyak $6,65 \mathrm{mg} / 100 \mathrm{~g}$ dan pigmen karotenoid paling dominan adalah $\beta$-karoten (Samson E., 2012). Hasil dari penelitian ini menunjukkan seperti dalam Tabel 3 karoten total dalam TPTL sebesar 7,92 mg/100 g dan beta karoten sebesar $1,47 \mathrm{mg} / 100 \mathrm{~g}$. Kandungan karoten yang merupakan pro vitamin $\mathrm{A}$ akan membantu memenuhi kebutuhan vitamin A sehari-hari. Dilengkapi dengan kandungan vitamin C sebesar 147,77 mg/100 
g yang akan memenuhi kebutuhan konsumsi vitamin $\mathrm{C}$ orang dewasa yaitu $45 \mathrm{mg}$ per hari (FAO, 2011). Kadar vitamin C TPTL juga jauh lebih tinggi dibandingkan tepung pisang kepok, lumut, siam, dan nangka yang diteliti oleh Histifarina, dkk. (2012).

Tabel 3. Total karotenoid, beta karoten, vitamin c, dan antioksidan TPTL

\begin{tabular}{lc}
\hline Parameter & Hasil \\
\hline Karoten total $(\mathrm{mg} / 100 \mathrm{~g})$ & $7,92 \pm 0,08$ \\
Beta karoten $(\mathrm{mg} / 100 \mathrm{~g})$ & $1,47 \pm 0,01$ \\
Vitamin C $(\mathrm{mg} / 100 \mathrm{~g})$ & $147,77 \pm 4,02$ \\
Flavonoid total $(\% \mathrm{~b} / \mathrm{b})$ & $0,35 \pm 0,01$ \\
DPPH IC50 $(\mathrm{mg} / \mathrm{mL})$ & 159,41 \\
\hline
\end{tabular}

Total flavonoid tepung pisang tongka langit sebesar $0,35 \mathrm{mg} / \mathrm{kg}$. Aktivitas antioksidan yang dinyatakan dalam IC50 sebesar 159,41 mg/mL. Berdasarkan nilai IC50 sifat antioksidan yang dimiliki TPTL yaitu sedang. Semakin kecil nilai IC50 $(<50)$ maka semakin tinggi aktivitas antioksidannya (Badarinath, 2010).

\section{KESIMPULAN}

TPTL yang dibuat dari buah pisang Tongka Langit yang masih masak (sudah layak dimakan tetapi masih belum matang) menghasilkan rendemen $25-28 \%$. TPTL mengandung kadar lemak cukup rendah dan kadar abu yang tinggi. TPTL memiliki kandungan mineral dan serat pangan tinggi yang baik dalam hal menurunkan resiko hipertensi dan stroke. TPTL juga memiliki kandungan antioksidan berupa karoten, vitamin C, dan flavonoid.

\section{UCAPAN TERIMA KASIH}

Terima kasih kepada Universitas Ciputra yang telah memberikan dana penelitian melalui HIP (Hibah Internal Penelitian) tahun 2017.

\section{KONFLIK KEPENTINGAN}

Penulis menyatakan bahwa artikel ini asli, belum pernah dipublikasikan, dan bebas dari konflik kepentingan.

\section{DAFTAR PUSTAKA}

Abdillah, F. (2010). Modifikasi Tepung Pisang Tanduk (Musa paradisiaca Formatypica) Melalui Proses Fermentasi Spontan dan Pemanasan Otoklaf untuk Meningkatkan
Kadar Pati Resisten. Tesis. Bogor: Sekolah Pascasarjana, Institut Pertanian Bogor.

American Heart Association. (2016). Whole Grains and Fiber. Diakses:25Mei2018. [http://www.heart.org/HEARTORG/ HealthyLiving/HealthyEating/HealthyDietGoals/WholeGrains-and-Fiber_UCM_303249_Article.jsp]

AOAC. (2016). Official Methods of Analysis of AOAC International, Edisi ke-18, Volume 1-2, Revisi 1. Maryland, USA: AOAC International. Association of Analytical Communities.

Badarinath, A., Rao, K., Chetty, C. S., Ramkanth, S., Rajan, T., \& Gnanaprakash, K. (2010). A review on in-vitro antioxidant methods: comparisons, correlations, and considerations. International Journal of PharmTech Research, 2010, 1276-1285.

Burda, S. \& Oleszek, W. (2001). Antioxidant and antiradical activities of flavonoids. J.Food Chemistry, 49 , 27742779. DOI: $10.1021 /$ jf001413m

da Mota, R. V., Lajolo, F. M., Ciacco, C., \& Cordenunsi, B. R. (2000). Composition and functional properties of banana flour from different varieties. Starch, 52, 63-68. https://doi.org/10.1002/(SICI)1521379X(200004)52:2/3<63::AID-STAR63>3.0.CO;2-V

Departemen Kesehatan RI. (1990). Kandungan Gizi Pisang. Diakses: 10 Februari 2017. [balitbu.litbang.pertanian. go.id/ind/images/filepdf/gizibuah.pdf]

Ekafitri, R., Sarifudin, A., \& Surahman, D. N. (2013). Pengaruh penggunaan tepung dan puree pisang terhadap karakterisitik mutu makanan padat berbasis-pisang. Penelitian Gizi dan Makanan, 36(2), 127-134.

FAO/WHO. (2011). Vitamin and mineral requirements in human nutrition: FAO/WHO in the $33^{\text {rd }}$ session of Codex Committee on Nutrition and Food for Special Dietary Uses (CCNFSDU).

Harefa, W. \& Pato, U. (2017). Evaluasi tingkat kematangan buah terhadap mutu tepung pisang kepok yang dihasilkan. FAPERTA, 4(2), 1-12.

Histifarina, D., Rachman, A., Rahadian, D., \& Sukmaya. (2012). Teknologi pengolahan tepung dari berbagai jenis pisang menggunakan cara pengeringan matahari dan mesin pengering. Agrin, 16(2), 12-133. jppertaniandd120161

Julkunen-Tiitto, R. (1985). Phenolics constituens in the leaves of northern willows: methods for the analysis of certain phenolics. J. Agric. Food Chem. 33, 213-217. https:// doi.org/10.1021/jf00062a013

Lattimer, J. M. \& Haub, M. D. (2010). Effects of dietary fiber and its components on metabolic health. Nutrients 2, 1266-1289. doi: 10.3390/nu2121266

Krummel, D. A. (2008). Medical Nutrition Therapy for Cardiovascular Disease. In: Mahan, L. K., Escott-Stump, S., Krausse's Food and Nutirition Therapy. Canada: Saunders Elsvier, 834-835. 
Nurhayati, Ruriani, E., \& Jayus. (2015). Pengembangan Tepung Berprebiotik sebagai Pangan Fungsional dari Pisang (Musa sp) Beberapa Varietas Unggulan Kabupaten Lumajang Provinsi Jawa Timur. Universitas Jember: Laporan Hasil Penelitian Hibah Bersaing. Diakses: 28 Mei 2018. [http://repository.unej.ac.id/ handle/123456789/61323]

Octavia, Z. F., Djamiatun, K., \& Suci, N. (2017). Pengaruh pemberian yogurt sinbiotik tepung pisang tanduk terhadap profil lipid tikus sindrom metabolik. Jurnal Gizi Klinik Indonesia, 13(4), 159-169. https://doi. org/10.22146/ijcn.19369

Palupi, H. T. (2012). Pengaruh jenis pisang dan bahan perendam terhadap karakteristik tepung pisang (Musa Spp). Jurnal Teknologi Pangan, 4(1), 102-120.

Gao, H. , Shaobo Huang, Tao Dong, Qiaosong Yang, \& Ganjun Yi. (2016). Analysis of resistant starch degradation in postharvest ripening of two banana cultivars: Focus on starch structure and amylases. Postharvest Biology and Technology, 119.

Pragati, S., Genitha, I., \& Ravish, K. (2014) comparative study of ripe and unripe banana flour during storage. J Food Process Technol 5, 384. DOI: 10.4172/21577110.1000384

Pramono, A., Noriko, N., \& Komara, S. B. (2017). Natrium dischargement from peripheral blood as a predominant factor influenced by the administration of banana (Musa paradisiaca) on elderly female hypertensive patient. IOP Conf. Ser.: Mater. Sci. Eng. 193012058 : 1-6. DOI: 10.1088/1757-899X/193/1/012058

Pratomo, A. (2013). Studi eksperimen pembuatan bolu kering substitusi tepung pisang ambon. FSCEJ 2(1), 17-30.
Pujiani, I., Nurapriyanti, I., Widyawati, M. N., \& Ulfiana, E. (2017). Effect of ambon banana consumption to decrease blood pressure in pregnant woman with preeclamps. $2^{\text {nd }}$ ICASH-A047 : 297-301.

Ristania, S. R., Martianawati, Supriyanto, S., \& Irawan, R. (2017). the effect of consuming ambon banana (musa paradisiaca var. sapientum) on sleep latency of elderly hypertension. Health Nations 1, 86-89. DOI: 10.33846/ hn.vli2.23

Samson, E., Semangun, H., \& Rondonuwu F. S. (2012). Analisis kandungan karotenoid ekstrak kasar buah pisang Tongka langit dengan menggunakan spektroskopi NIR. Trad. Med. J. 18, 17-21.

Samson, E., Semangun, H., \& Rondonuwu F. S. (2013). Analisa lama waktu pemanasan terhadap stabilitas pigmen karotenoid buah pisang tongka langit ukuran panjang. Prosiding FMIPA Universitas Pattimura.

Sudarmadji, S., Haryono, B., \& Suhardi. (2010). Analisa Bahan Makanan dan Pertanian, Edisi kedua, Cetakan keempat. Yogyakarta: Penerbit Liberty.

Suryana, A., Hidayat, D. S., Wirawanto, D. I., Welirang, F., Subiyanto., Samawi M. I., Rustriningsih, Margono, S., Widodo, S., Usman, S., Suparmo, Fatah, S. A., Dipo, T. S., Tranggono, Utomo W. H. (2004). Politik Pangan. Center for Indonesian Research and Development. Yogyakarta.

Wahyuningtyas, N., Basito, Atmaka, W. (2014). kajian karakteristik fisikokimia dan sensoris kerupuk berbahan baku tepung terigu, tepung tapioka dan tepung pisang kepok kuning. Jurnal Teknosains Pangan 3(2), 76-85. 